\title{
Fecundity and Egg Size of Clarias Gariepinus in Pandam Lake, Quan-Pan L.G.A.Plateau State, Nigeria
}

\author{
K. V. Absalom ${ }^{1}$, J. A. Anpe ${ }^{2}$, L. E. Igoche ${ }^{3}$, S. A. Okunsebor ${ }^{4}$ \\ ${ }^{1 \& 2}$ Department of Zoology, Faculty of Natural Sciences, University of Jos, University of Jos, Plateau State, \\ Nigeria, West Africa. \\ ${ }^{3}$ Department of Animal Production, Faculty of Agriculture, University of Jos, Plateau State, Nigeria. \\ ${ }^{4}$ Department of Aquaculture and Fisheries Management, Faculty of Agriculture, Nasarawa State \\ University keffi.
}

\begin{abstract}
Experimental trials were conducted to evaluate the fecundity and egg size of Clariasgariepinus brooders (700 - 990g) in Pandam Lake, Plateau State, Nigeria. Thirty female fish were caught using gill nets and long-line gears. In addition, fishermen's catch was also sampled to increase sample size and fish size. Fish were dissected and their ova sac removed, weighed and preserved in 5\% formalin to prevent quick egg-freezing action before counting. An ocular micrometer $(M g=0.019 \mathrm{~mm})$ was used to obtain the egg size. Regression analysis was applied to assess the total length and body weight, total length and fecundity, body weight and fecundity dependence of the brooders. A unit increase in the length of the fish lead to 0.52g increase in the body weight. Between total length and fecundity, there is a significant connection with p-value less than the level of significance at $(p>0.05)$ with a very high value of coefficient of correlation at $r=0.988$. Similar results were obtained for body weight and fecundity but with the coefficient of correlation at $r=0.917$. Absolute fecundity and relative fecundity were found to be related to the body weight of the fish. Each of these relationships is statistically significant $(p<0.05)$. The egg size ranged between $1.13 \mathrm{~mm}$ to $1.16 \mathrm{~mm}$. The result indicates that the relative fecundity increased with increasing body weight and total length.
\end{abstract}

Keywords: Brooders, Fecundity, Egg size, Gonado Somatic Index, and Pandam Lake.

\section{Introduction}

Clarias gariepinus is found in Lake Pandam, Plateau State. It is often consumed forits commendatory biological and socio-economic attributes. Such attributes are high growth rate, high fecundity, very resistant to stress and disease. Like Clarias angurilaris, it is equally hardy and palatable which makes it attractive to consumers (Ezenwaji, 1985; Eyo et al., 2016). The world population is increasing as is the demand for protein. Aquaculture, the fastest growing food production sector (Jia et al., 2001) has the potential to help address the world's growing food demand, play an important role in future by providing food and employment for people in Nigeria and Africa at large (FAO, 2014; Miller et al., 2002).

Adequate supply of $C$. gariepinus fry and fingerlings which are of great commercial importance is one of the major problems to modern fish farming (Aguigwo, 1999). Under controlled conditions, attempts are made to obtain the highest possible numbers of good quality hatchlings (Brzuska, 2003). Fecundity is an index which measures the number of eggs carried by a gravid female fish or shrimp (Eyo et al., 2013). Knowledge of the fecundity of fishes is important for the comprehension of their life history (King, 1997). Colour, shape and size of eggs are also important parameters used in reproduction studies to characterize fish species and can also be used to predict the spawning frequency of fish (Wootton, 1979). Gonado somatic index (GSI) is one of the parameters that can also be used in reproduction studies of fish. The use of GSI to detect hydrated ovaries and therefore detect reproductive period from increase in weight has been established by (Hunter \& Macewicz 2001). This study is therefore aimed at determining some aspects of reproduction, namely, fecundity, egg size and GSI of Clarias gariepinus in Pandam Lake, North-Central Nigeria, with a view of bridging the gap in knowledge and providing scientific information for enhancing its management in Plateau State.

\subsection{The Study Area}

\section{Materials And Methods}

Clarias gariepinus broodstock were obtained from Pandam in Qua'an Pan Local Government Area of Plateau State, Nigeria. It lies between the central coordinates of $9^{0} 3.00^{\prime}$ East $8^{0} 4.00^{\prime}$ North and located beside the Lafia-Shandam road to the north of the Benue River. It covers an area of 22,400 hectares and has an altitude of $175-315 \mathrm{~m}$. The fishes were then transferred to the automated thermo-controlled fish hatchery of Global Aquaculture and Allied Ventures (GAAV) in Jos-South, Plateau State where the experiment was carried out. 
Fecundity and Egg Size of Clarias Gariepinus in Pandam Lake, Quan-Pan L.G.A.Plateau State, ..

\subsection{Experimental Design}

A total Sample of thirty (30) females Clariasgariepinus brooders $(700-990 \mathrm{~g})$ were caught in the month of May, 2015 using gill nets and long-line gears. Females with soft, distended belly and pink-red genital papilla were selected and their total lengths and weights were recorded. The fishes were transferred and kept in concrete tanks of $2 \mathrm{~m} \times 2 \mathrm{~m} \times 0.7 \mathrm{~m}$. Each female brooder was sacrificed, dissected and the ovary sac taken out. The ovary sac weights were recorded and preserved in 5\% formalin to prevent its quick egg-freeing action. Three samples of eggs $(1 \mathrm{~g})$ each were weighed from each ovary and the matured eggs were segregated from the immature eggs and the ovarian tissues. The weight of the immature eggs and ovarian tissue were determined and the values were subtracted from the weight of the $1 \mathrm{~g}$ sample of the ovary observed. The remaining value gave the weight of the matured eggs. Matured eggs were counted and recorded. The average values from the remaining two egg sample of the ovary were also determined. Ten eggs from each ovary were picked at random, and their diameter measured using a calibrated micrometer mounted on the eyepiece of a monocular microscope $(1$ division $=0.02 \mathrm{~mm})$.

The Gonado Somatic Index (GSI) which is the percentage of gonad weight to the total tissue weight of the fish was calculated for each of the female separately using the formula;

GSI $=$ Weight of gonad $\times 100 \quad$ (Barber \& Blake, 2006)

Weight of tissue

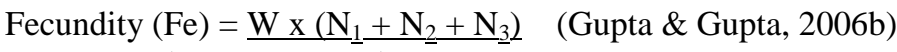

$\left(\mathrm{W}_{1}+\mathrm{W}_{2}+\mathrm{W}_{3}\right)$

Where:

$\mathrm{F}=$ Fecundity;

$\mathrm{W}=$ Total weight of ovary;

$\mathrm{W}_{1}, \mathrm{~W}_{2}, \mathrm{~W}_{3}=$ Weight of each subsample;

$\mathrm{N}_{1}, \mathrm{~N}_{2}, \mathrm{~N}_{3}=$ Ova counts in subsamples.

\subsection{Data Analysis}

From the above data, the relationship of different parameters such as total length and body weight, total length and fecundity, body weight and fecundity were determined as simple linear relationship using SPSS Statistics Version 21, coefficient of correlation $(\gamma)$ and regression equation were determined.

\section{Results}

Fish fecundity in this study ranged from 8,545 to 43,976 with a mean of 25,664 and the GSI values obtained ranged from 1.39 to 5.27 with a mean of 3.54 while the egg sizes ranged from $1.13 \mathrm{~mm}$ to $1.16 \mathrm{~mm}$. For each brooder the results show that there is a positive influence in the relationships. Between the total length and body weight shows that the independent (Total length) variable contribute to $92 \%$ of body weight of fish. From the ANOVA statistics shown in Table 1, the processed data, which are the population parameters, are all significantly different $(\mathrm{p}<0.05)$ i.e. there is a significant relationship between fish body weight and its total length.

The coefficient of regression from table 1 was by a linear equation.

$\mathrm{Y}=\mathrm{a}+\mathrm{bX}$

Where $\mathrm{a}$ and $\mathrm{b}$ are constant, $\mathrm{X}$ is the body weight and $\mathrm{Y}$ is dependent variable, the $\mathrm{p}$-value was less than 0.05 at $95 \%$ confidence level. Meaning the fish length has an effect on the body weight significantly. A unit increase in the length of the fish will lead to 0.519 unit increase in body weight. The result between the total length and fecundity (Table 2) reveals that there is a significant connection between total length and fecundity with $p$-value less than the level of significant at $(\mathrm{p}<0.05)$. The result indicates that the extent of the relationship is very high with the value of the coefficient of correlation as $r=0.988$. The coefficient of determination $R$ square indicates that $98 \%$ of the variation in the dependent variable is being explained by the independent variable. For the result on body weight and fecundity (Table 3) the output reveals that there is a significant connection between body weight and fecundity with $p$-value less than the level of significant $(p>0.05)$. The result further indicate that the extent of the relationship is very high with coefficient of correlation $r=0.917$. The coefficient of determination $\mathrm{R}$ square indicates that $84 \%$ of the variation in the dependent variable is being explained by the independent variable. Absolute fecundity and relative fecundity were found to be related in the body weight of the fish. The relative fecundity increases with increasing body weight and total length. Each of these relationships is statistically significant $(\mathrm{p}<0.005)$. The matured ova diameters ranged from $1.13 \mathrm{~mm}$ to $1.16 \mathrm{~mm}$. 
Fecundity and Egg Size of Clarias Gariepinus in Pandam Lake, Quan-Pan L.G.A.Plateau State, ..

Table 1: Regression for Length versus body weight of Clarias gariepinus in Pandam Lake

\section{Model Summary}

\begin{tabular}{lllll} 
Model & $\mathrm{R}$ & R Square & Adjusted R Square & Std. Error of the Estimate \\
\hline 1 & $0.958^{\mathrm{a}}$ & 0.918 & 0.917 & 0.28314
\end{tabular}

Note: $a=$ Predictors: (Constant), length $(\mathrm{cm})$

Table 2: Regression for length versus fecundity of Clarias gariepinus in Pandam Lake

Model Summary

\begin{tabular}{lllll} 
Model & R & R Square & Adjusted R Square & Std. Error of the Estimate \\
\hline 1 & $0.988^{\mathrm{a}}$ & 0.975 & 0.975 & 0.28713
\end{tabular}

Note: $a=$ Predictors: (Constant), fecundity.

Table 3: Regression for Body weight versus fecundity of Clarias gariepinus in Pandam Lake

Model Summary

\begin{tabular}{lllll}
\hline Model & $\mathrm{R}$ & R Square & Adjusted R Square & Std. Error of the Estimate \\
\hline & & & \\
1 & $0.917^{\mathrm{a}}$ & 0.841 & 0.838 & 0.39512 \\
\hline
\end{tabular}

Note: $a=$ Predictors: (Constant), fecundity.

\section{Discussion}

The GSI values obtained ranged from 1.39 to 5.27 with a mean of 3.54. This showed that all the brooders have a high GSI and these ranges are within those observed by (Admassu et al., 2015). The high values of GSI in the brooders were due to increase in the ovary sac weight which means more eggs are contained in the ovary sac. The GSI of this study corresponds with the result obtained by Offem, et al. (2008) who stated that the GSI of Heterobranchus longifilis was higher in the rainy season which falls within the period of this study. The GSI of this study is also similar with the work of Saliu \& Fagade, (2003) who reported higher GSI values in Brycinnus longipinnis in Asa reservoir. Absolute and relative fecundity increases with increasing body weight of the fish. The fecundity of this study ranges from 8,545 to 43,976 with a mean value of 25,664 . There were wide variations in the number of eggs, with larger brooders producing more eggs than the smaller ones, which may probably be due to more available visceral volume for holding the eggs in the body of the larger females before spawning. Variation in fecundity may also be due to the difference in the age and classes of the brooders (Saliu, et al.2007). In many species fecundity is shown to correlate with body weight and total length and is used to measure the relationship between the number of eggs and weight of the fish (Gupta and Gupta 2006). The absolute fecundity increases with each spawning (Abayomi \& Arawomo 1996). As a result, the number of eggs produced per fish in a year is significantly higher in the tropics as reported by Alikunhi (1966) on Cyprinus carpio. The fecundity of a ripe fish is related to length (total length = TL) and spawning capability is very closely related to ovary weight. This study agrees with a work reported by Douglas (2008) on the spawning behaviour in Clarias lazera which follows the same spawning pattern as found in this study. The large egg sizes which ranged between $1.13 \mathrm{~mm}$ to $1.16 \mathrm{~mm}$ in this study enhanced larval and fry viability due to its higher yolk content, and hence food supply to the newly hatched larva as stated by Hulata et al., (1974). Thus, large egg size 
in Clarias gariepinus may be an indication of better larval viability. Though, such matured egg sizes were encountered in the month of May-June in this study, they were found too predominating in June and July or even August months coinciding with the onset of the rains and flooding (Gupta et al., 2006c).

\section{Conclusion}

The result obtained from this study indicates that absolute fecundity and relative fecundity of Clarias gariepinus were related to the body weight of the fish. Each of these relationships is statistically significant ( $\mathrm{p}$ $<0.05$ ). The egg size ranged between $1.13 \mathrm{~mm}$ to $1.16 \mathrm{~mm}$. This result also shows that the relative fecundity increased with increasing body weight and total length of the fish.

\section{References}

[1]. Abayomi, O.S. and G.A.O. Arawomo, (1996).Sex-ratio and fecundity of catfish (Clariasgariepinus) in Opa reservoir, Obafemi Awolowo University, Ile-Ife. In: $13^{\text {th }}$ Annual Conference of the Fisheries Society of Nigeria (FISON). Transactions of the Fisheries Society of Nigeria, 1, 122-130

[2]. Admassu, D., Abera, L., and Z. Tadesse, (2015). Fecundity and breeding season of the African Catfish Clarias gariepinus (Burchell), in Lake Babogaya, Ethiopia. Global Journal of Agricultural Sciences, 3 (8), 295 - 303.

[3]. Aguigwo, J. N., (1999). Studies on the biology of larvae of Clariasalbo punctatus: Effect on different diets on the growth and survival of larvae. Journal of Aquatic Sciences, 14, 29-32.

[4]. Alikunhi, K. H., (1966). Synopsis of biological data on common carp, Cyprinus carpio Linnaeus, 1758 (Asia and the Far East).FAO Fish Synopsium.(31.1), p83.

[5]. Barber, B.J. \& N.J. Blake, (2006). Reproductive Physiology. In: S.E. Shumway and G.J. Parsons, editors. Scallops: biology, ecology, and aquaculture, $2^{\text {nd }}$ edition. Amsterdam, The Netherlands: Elsevier. pp 357-416.

[6]. Brzuska, E. (2003). Artificial propagation of African Catfish (Clarias gariepinus): Differences between reproduction effects after stimulation of ovulation with carp pituitary homogenate or GnRH-a and Dopaminergic Inhabitor. Czech Journal of Animal Sciences, 48, (5), 181-190.

[7]. Clark, F.N. (1934). Maturity of California sardine (Sardinella cacrulea) determined by ova-diameter measurements. California Fish Game, Bulletin. No, 1-23.

[8]. Douglas, C., (2008). Sexual maturity and fecundity of the African catfish (Clarias gariepinus) with an observation on the spawning behavior of the Nile catfish (Clarias lazera). Zoological Journal of the Linnean Society, 65 (4), 351-365.

[9]. Eyo, V.O, Ekanem, A.P, Eni G and A.P. Edet, (2013).Relationship between fecundity and biometric indices of the silver catfish Chrysichthys nigrodigitatus (Lacepede) in the Cross River estuary, Nigeria. Croat Journal of Fish, 71, 131-5.

[10]. Ezenwaji, H.M.G. (1985). African Clarias Taxonomy, Impetration for the field worker. Proceedings of the $4^{\text {th }}$ Annual Conference of the Fisheries Society of Nigeria (FISON).26 ${ }^{\text {th }}-29^{\text {th }}$ Nov. Port-Harcourt, Nigeria. Pp. 191-196.

[11]. Food and Agriculture Organization of the United Nations, (2014).The state of world fisheries and aquaculture. Rome: Food and Agriculture Organization of the United Nations; 2014 (online) Available from: http://www.fao.org/3/a-i3720e/index.html (Accessed on 20th March, 2016)

[12]. Gupta, S.K. and P.C. Gupta., (2006a). General and Applied Ichthyology: Fish and Fisheries. S. Chand and Co. LTD., Ram Nagar, New Delhi, India, pp. 1130.

[13]. Gupta, S.K. and P.C. Gupta., (2006 b). General and Applied Ichthyology: Fish and Fisheries. S. Chand and Co. LTD., Ram Nagar, New Delhi, India, pp. 851-852.Gupta, S.K. \& P.C. Gupta., (2006c). General and Applied Ichthyology: Fish and Fisheries. S.Chand and Co. LTD., Ram Nagar, New Delhi, India, pp. 855-857.

[14]. Hulata, G., Moav, R. and Wohlfarth, G. (1974).The relationship of gonad and egg size to weight and age in the European and Chinese races of common carp, Cyprinus carpio L. Journal of Fish Biology, 6, 745-758.

[15]. Hunter, J.R. and B.J. Macewicz, (2001).Improving the accuracy and precision of reproductive information used in fisheries: modern approaches to assess maturity and fecundity of warm- and cold-water fish squids. Fishery bulletin, 90(1), 101-128.

[16]. Jia, J., Wijkstrom, U., Subasinghe, R.P. \& U. Barg, (2001). Aquaculture development beyond 2000: global prospects, Keynote Address II. In R.P. Subasinghe, P. Bueno, M.J. Phillips, C. Hough, S.E. Mc Gladdery and J.R. Arthur, eds. Aquaculture in the Third Millennium. Technical Proceedings of the Conference on Aquaculture in the Third Millennium, Bangkok, Thailand, 20-25 February 2000. pp. 9-12.

[17]. King, R.P. (1997). Weight-fecundity relationships of Nigerian fish populations. NAGA, the ICLARM quarterly, 22(1), 33-36.

[18]. Miller, L.M., A.R. Kapuscinski and W. Senanan, (2002). A biosafety approach to addressing risks posed by aquaculture escapees. Expert consultation on biosafety and environmental impact of genetic enhancement and introduction of improved tilapia strains/alien species in Africa. Nairobi, Kenya. Journal of Fisheries and Aquaculture Sciences, 59 (2), $282-290$.

[19]. Offem, B.O., Ayotunde, E.O. and G.U. Ikpi, (2008). Dynamics in the reproductive biology of Heterobranchus longifilis Val., (Pisces: 1840) in the wetlands of Cross River, Nigeria. Research Journal of Fisheries and Hydrobiology, 3(1), 22-31.

[20]. Saliu, J.K. and S.O.Fagade, (2003). The reproductive biology of Brycinnus nurse (Paugy, 1986). (Pisces: Characidae) in Asa Reservoir, Ilorin, Nigeria. Turkish Journal of Fisheries and Aquatic Sciences, 3, 5-9.

[21]. Saliu, J.K., Ogu, J. and C. Onwuemene, (2007). Condition factor, fat and protein content of five fish species in Lekki Lagoon, Nigeria. Life Science Journal, 4(2), 54-57.

[22]. Wootton, R.J. (1979). Energy costs of egg production and environmental determinants of fecundity in teleosts fishes. In: P.J. Miller (Ed) Fish Phenology: Anabolic Adaptiveness of Teleosts, 44,133-159. 